\title{
Javaslatok az orvosképzés átalakítására (A magyar orvostudományi elit az egyetemeken és a Magyar Tudományos Akadémián) 1947-1948
}

\author{
N. Szabó József dr.
}

\begin{abstract}
A tanulmány „A tudományos elitek és a politika (1945-1948)” című monográfia része. A témában feltártam és rangos folyóiratokban publikáltam a politikai pártoknak a különböző elit csoportokhoz: agrártudományi, bölcsész, gazdaságtudományi, jogtudományi, múszaki és természettudományi elithez való viszonyát, illetve az egyes eliteknek a tudományos életen belül játszott szerepét. A dolgozat új források felhasználásával mutatja be a különböző szakmai csoportoknak és politikai erőknek 1947-1948-ban az orvosképzés átalakítására tett javaslatait. Feltárja továbbá az orvostudományi elit helyzetét az egyetemeken és a Magyar Tudományos Akadémián. A kutatás révén így képet kapunk a háború utáni „teljes” orvostudományi elitről. Megtudjuk, hogy kik és milyen tudományos teljesítmény alapján lettek az MTA tagjai, kiket neveztek ki egyetemi tanárnak és kik lettek habilitált doktorok. A tanulmány hiányt pótló munka, a kutatók mellett szélesebb értelmiségi rétegek, elsősorban az orvosok érdeklődésére is számíthat. Orv. Hetil., 2017, 158(11), 432-437.
\end{abstract}

Kulcsszavak: orvosképzés reformja, professzori kinevezések, habilitációk, orvos akadémikusok az MTA-n

\section{Suggestions of reshaping medical education (The Hungarian medical elite at universities and the Hungarian Academy of Sciences) 1947-1948}

This study is part of the monograph entitled Scientific Elites and Politics (1945-1948) to be published soon. The relationships of political parties with several elite groups, such as groups of agronomic, human, economic, legal, technical and natural sciences, as well as the roles of these elites in scientific life, have been looked into and published in renowned periodicals. Using new sources, different specialist groups' and political powers' suggestions of reshaping medical education in 1947 and 1948, are presented. The medical elite's situation at universities and the Hungarian Academy of Sciences is also outlined. The study renders an account of the entire post-war medical elite. It will be stated who and based on what scientific achievement became member of the Hungarian Academy of Sciences, who was appointed to professor and who became a habilitated doctor. This study, which is a desideratum of research, may not only interest researchers but is aimed at a broader readership, including physicians.

Keywords: reform of medical education, appointments of professors, habilitations, physicians as members of the Hungarian Academy of Sciences

N. Szabó, J. [Suggestions of reshaping medical education (The Hungarian medical elite at universities and the Hungarian Academy of Sciences) 1947-1948]. Orv. Hetil., 2017, 158(11), 432-437.

(Beérkezett: 2016. december 5.; elfogadva: 2017. január 24.)

\section{A medikusképzés helyzete}

A magyar felsőoktatás egyik legszínvonalasabb területe az orvosképzés volt, ezért itt a háború után alapvető szakmai modernizálásra nem is volt szükség. Ez a magyarázata, hogy az orvosképzés reformjával a politikai pár- tok 1945 első felében nem foglalkoztak. A Vallás és Közoktatási Minisztérium (VKM) sem a medikusképzés tartalmi kérdéseinek tulajdonította a legnagyobb jelentőséget, hanem a harcok alatt kárt szenvedett klinikai épületek helyreállításának. Néhány reformjavaslat a képzés demokratizálását kívánta előmozdítani. 
Tartalmi változások 1945 második felében sem voltak. A politikai pártok, a Magyar Kommunista Párt (MKP) kivételével, az 1945-1946-os tanévben sem foglalkoztak az orvosképzéssel. Az MKP-nak elsősorban a budapesti orvoskaron kialakuló nagy hallgatói létszám, illetve a medikusok többségének polgári politikai nézete miatt nőtt meg az érdeklődése. Az orvosképzéssel kapcsolatos bizonyos kérdésekkel a budapesti Medikus-kör, a VKM és az Orvos Szakszervezet foglalkozott.

1946 őszén a pártok részéről már megnőtt az érdeklődés az orvosképzés iránt, ami elsősorban az orvoskarokon kialakult rossz képzési körülményekkel függött össze. November elején a Szociáldemokrata Párt Orvoscsoportja akciót indított az Orvostudományi Kar (OTK) megsegítésére. A csoport úgy ítélte meg, hogy bármilyen lelkes is a tanári kar, a karon olyan nagyok a hiányosságok, hogy megoldhatatlanná teszik a tanítást és a képzést. A szociáldemokraták nagy veszélyt láttak abban is, hogy a háború előtt nemzetközileg is elismerték a magyar diplomákat, de az utóbbi időben már nehézségek jelentkeztek. Az orvosképzés problémáinak megoldására a szociáldemokrata párt orvosprofesszorok bevonásával bizottságot hozott létre. A bizottság elhatározta, hogy feldolgozza az egész kérdés komplexumát és az erről készült emlékiratot eljuttatja a kormányhoz és sürgős pótköltségvetés elkészítését kéri. ${ }^{1}$

A Független Kisgazdapárt is nagy jelentőséget tulajdonított az orvosképzésnek, ezért orvoscsoportja Reök István (1894-1967) elnökletével 1946. november közepén ankétot rendezett a képzés reformjáról. Az ankéton a kisgazdákon kívül részt vett még a kommunista Mansfeld Géza (1882-1950) professzor és Zsebök Zoltán (1908-1984) miniszteri osztályfőnök is. Zsebők az orvosképzés legsúlyosabb problémájának az orvostúlképzést és a magyar orvosi diploma nemzetközi devalválódását tartotta. Legfontosabb feladatnak az orvostúlképzés elleni küzdelmet és a magyar diplomáknak a külföldiekkel azonos kulturális és tudományos nívóra való emelését tartotta. A megoldandó feladatok közé sorolta még a tudósképzést, az orvosképzés időtartamának észszerü megoldását, valamint a gyakorlati szakmák előtérbe helyezését a tisztán elméleti tárgyakkal szemben. ${ }^{2}$ A budapesti orvosképzés problémáit valamelyest csökkentette, hogy a munkásság segítségével a „Munkások a tudományért” akció keretében újjáépült az Élettani Intézet, ${ }^{3}$ illetve helyreállították a budapesti fül-orr-gégészeti klinikát, a röntgenklinikát és az anatómiai intézetet. 1947-ben elkészült a tbc-klinika is.

Az 1946-os évben az SZDP-t továbbra is elsősorban az orvosi diploma devalválódása foglalkoztatta. A Népszava ezért interjút készített Melley József (1893-1962)

\footnotetext{
Népszava, 1946. november 6

Kis Újság, 1946. november 17

3 Szabad Nép, 1946. november 26.; Országgyülés Naplója, III. kötet. Hiteles Kiadás, Athenaeum Irodalmi és Nyomdai Részvénytársulat Könyvkiadója, Budapest, 1948, 583. oldal.
}

orvosprofesszorral. A professzor is elismerte, hogy a korábban nemzetközi megbecsülésnek örvendő magyar orvosi diplomát az utóbbi időben több minden kikezdte. A közegészségtan-tanszék vezetője a probléma okát a háborús pusztításban, az eszköz- és anyaghiányban, valamint a külfölddel megszakadt tudományos kapcsolatokban látta. ${ }^{4}$

Mivel az orvosképzés területén a legnagyobb gondot a rossz képzési körülmények jelentették, ezért a politika is elsősorban erre figyelt fel. A problémával a szakmán kívül a pártok közül leginkább a Szociáldemokrata Párt, a Magyar Kommunista Párt, illetve a Kisgazda Párt foglalkozott. A megoldás előmozdítására a Pázmány Péter Tudományegyetem Orvostudományi Kara 1947. február 9-én „Orvostudományunk a nemzetért - nemzetünk az orvostudományért” címmel ankétot rendezett, amelynek fóvédnöke Tildy Zoltán kisgazdapárti köztársasági elnök volt. Tildy Zoltán felszólalásában elismerte a magyar orvostudomány nemzetközi presztízsét és azt, hogy ezzel Magyarországnak is megbecsülést szerzett. Az ankéton szintén jelen lévő Nobel-díjas Szent-Györgyi Albert (1893-1986) hozzászólásában arra helyezte a hangsúlyt, hogy miután a nemzet kezd magához térni, kötelessége, hogy a tudományt támogassa, mert e nélkül a demokrácia frázis marad. ${ }^{5}$

1947 februárjában a budapesti Medikus-kör reformterveket dolgozott ki, amelyet az OTK baloldali tanárai - elsősorban Rusznyák István (1889-1974) - is támogattak, és amelyet a vidéki egyetemek Medikus-körei is elfogadtak (Ladányi Andor: A felsőoktatás szocialista átszervezésének kezdete: az 1948. évi egyetemi reform. Magyar Pedagógia, 1970. 174.)

A parasztpárti B. Farkas Ferenc is rendkívül fontosnak tartotta az orvosképzés reformjának megvalósítását, amit a VKM-költségvetés 1947. március 12 -i vitájában indítványozott. ${ }^{6}$ Ugyanakkor a kommunista Rudas László is reformot szorgalmazott. Szót emelt, hogy a klinikák a legszükségesebbeknek is híján vannak és hogy a tudományos kutatás majdnem lehetetlenné vált. A kommunista szónok a képzés színvonalának növelése érdekében a fiziológiai tanszék betöltését kezdeményezte, mert orvosképzés fiziológia nélkül lehetetlen. ${ }^{7}$

1947 tavaszától az orvosképzés problémája nem kapott megfelelő hangsúlyt a pártok politikájában. 1947ben, a politikai elbizonytalanodás idején, a demokrácia léte volt a leglényegesebb kérdés a polgári demokrácia talaján álló pártok számára.

Az orvostanhallgatókat viszont foglalkoztatta a doktori cím tervezett reformja körüli probléma. Rendelet készült ugyanis, amelynek egyik fontos alappontja az volt, hogy az orvosoknál csak az egyetemi magántanári képesítés jogosítana a doktori cím használatára, a gyakorló

\footnotetext{
Népszava, 1946. december 22

Kis Újság, 1947. február 11.

Nemzetgyülés Naplója, VI. kötet. Hiteles Kiadás, Budapest, 1952, 608. oldal. Nemzetgyülés Naplója, VI. kötet, 663. oldal.
} 
orvos csupán „orvos” megjelölést használhatott volna. A rendelet abból indult ki, hogy a gyógyító orvos esetében nem lényeges a doktori cím, minthogy tudományos múködést nem fejthet ki. Február l4-én a szigorló orvosok az orvosszakszervezet tanácstermében rendkívüli ülést hívtak össze, hogy tiltakozzanak a készülő rendelet ellen. Az orvosjelöltek azon a véleményen voltak, hogy a tervezet megzavarná és gátolná a medikusok munkakedvét. Hasonló gyúlést rendezett a Royal Appolóban a Medikus-kör is. A nagygyuulésen a Vallás- és Közoktatásügyi Minisztériumot képviselő Zsebők Zoltán a medikusok megnyugtatására kifejtette, hogy a javaslat elsősorban nem az orvostanhallgatókra, tehát nem az orvosdoktori címre, hanem a négy esztendő alatt megszerezhetó egyéb doktori kvalifikációra vonatkozik. ${ }^{8}$ Az orvosképzés és a doktori cím körüli polémiában a Kisgazda Párt is véleményt nyilvánított a parlamenti ülésen.

Reök István kisgazdapárti képviselő 1948. február 23-i felszólalásában az orvosképzés egyik fó hiányosságának az orvosetikai oktatás hiányát tartotta, ezért a tárgy oktatását követelte. A Független Kisgazda Párt orvoscsoportjának vezetóje az orvosképzés hibájának tartotta azt is, hogy a képzés át van itatva a német szellemtől, ami abból áll, hogy a fiatal orvosokkal megtanítanak lexikális ismereteket, ugyanakkor az emberrel, a beteggel való törődést nem tanították meg. Reök István felszólalásában foglalkozott a doktori fokozat tervezett reformjával. A kisgazdapárti orvos vezetô a doktori cím eltörlését helytelenítette, mert megítélése szerint az orvosképzésnél figyelemmel kell lenni az ambíciókra és a törekvésekre is. ${ }^{9}$

1948-ban a kommunisták politikájában újból fontossá válik a felsőoktatási politika, amiben az orvosképzéssel is foglalkoztak. A párt értelmiségi osztálya által 1948. június 8-án elkészített felsőoktatási reformtervnek azonban a legkevésbé kidolgozott része az orvosképzés volt. A kommunista tervezet elismerte, hogy a többi szakterülethez képest az orvosképzés aránylag a legkielégítőbb, de ennek ellenére úgy ítélte meg, hogy mélyreható reformra van szükség. A képzés legfóbb gyengeségének azt tartotta, hogy a német rendszer mintájára alakult ki és az utóbbi három évtizedben alig fejlődött, a tanítás elméleti jellegú volt és az oktatás háromnegyed részben a professzori előadásokból állt. Problematikusnak tartotta a képzést azért is, mert az orvostudomány egyes ágait amelyek az egészségvédelem és a tömeggyógyítás szempontjából döntôen fontosak - vagy egyáltalán nem, vagy nem megfelelően tanítják.

A reform a képzés egyik céljának azt fogalmazta meg, hogy olyan orvosokra van szükség, akik tisztában vannak a falu és az üzemek legfontosabb egészségügyi problémáival és gyakorlati tudással rendelkeznek.

\footnotetext{
8 Szabad Szó, 1948. február 15.

9 Országgyúlés Naplója, III. kötet, 520-521. oldal.
}

A kommunista elképzelés szerint a professzorok hetente tartanának előadásokat, amikor a tudományos kutatás szellemével és legújabb irányaival ismertetnék meg a hallgatókat. A kötelező tananyagot laboratóriumokban, kórtermekben szemináriumszerúen a magántanárok tanítanák. A hallgatókat a tervezet 20 fös csoportokba kívánta osztani. Ezek a csoportok legalább egy éven át állandóak maradnának. Összetartásukról és politikai nevelésükről egy, a Medikus-kör által kijelölt tagjuk gondoskodna. Az MKP-tervezet a tantervet úgy kívánta átalakítani, hogy a csecsemő- és gyermekgyógyászat, a szülészet, valamint az iparegészségügy elméleti és gyakorlati oktatására a tanulmányi időszak jelentősen nagyobb idejét fordítanák.

$\mathrm{Az}$ egyetemi befogadóképesség és a szükségletek egyeztetése után az MKP-tervezet a budapesti orvoskarra 200, a vidéki karokra évenként 70-70 hallgatót kívánt felvenni. A kommunista javaslat szerint a felvétel csak szigorú felvételi vizsga alapján történhetne. A reformmal összefüggésben az MKP a következő személyi változásokat javasolta: A budapesti orvoskarról négy egyetemi tanár eltávolítását kezdeményezte: Melly, Földvári, Mónay és Kovács professzorokat, Szegedről pedig Purjesz Bélát (1884-1959) kívánta elküldeni. ${ }^{10}$

A kommunista tervezetnek, amely több hasznos elképzelést tartalmazott és bevezetése szakmailag is indokolt lehetett volna, több problematikus része volt. Az egyik leginkább kritizálandó terület a „káderpolitika” volt. Felületességre utal a budapesti orvosi karról eltávolítandó oktatók keresztnév nélküli felsorolása. Tudománypolitikai hiba volt a szakmailag és tudományosan jelentôs professzorok tervezett eltávolítása. Idetartozik Melly József, akinek iskolaorvosi tevékenysége komoly teljesítménynek számított. Hasonlóan hibás volt Purjesz Béla eltávolítási kezdeményezése. Purjesz kiváló belgyógyász volt és a rosszindulatú daganatokra vonatkozó megállapításait is jegyezte a szakma. Kanyó Bélának (1898-1964) a növényvédő szerek és más porártalmak mezőgazdasági munkahigiéniájára vonatkozó kutatásai ugyancsak jelentősek voltak.

Az MKP tervezetét a Magyar Dolgozók Pártja (MDP) Köznevelési Bizottsága 1948. június 22 -én együttes ülésén vitatta meg, és azt a tartalmi és szervezeti kérdéseket illetően egyes módosításokkal elfogadta. Ezt követően a VKM négy reform-elókészítő bizottságot küldött ki, majd ezután a reformtervek rövid idő alatt elkészültek. A kérdéssel az MDP Köznevelési Bizottsága és Tudományos Bizottsága, az Agitációs és Propaganda Bizottság, valamint a Politikai Bizottság is foglakozott. (Ladányi Andor: Mennyiségi fejlődés és strukturális változások. A felsőoktatás útja a felszabadulás után. TankönyvkiadóOktatáskutató Intézet, Budapest, 1989.)

A különböző bizottsági egyeztetések és megbeszélések után a kormányrendelet 1948. október 15-én kapott

${ }^{10}$ Párttörténeti Intézet Archívuma (PTI-Arch.) 274-21/74. 
nyilvánosságot. Ha a Köznevelésben publikált kormányrendeletet összehasonlítjuk az értelmiségi osztály által június 8-án készített nem nyilvános tervezettel, több területen lényeges módosításra figyelhetünk fel. A legnagyobb „változás” az volt, hogy az orvosképzés - a felsőoktatás más területeivel szemben - nem szerepelt az őszi egyetemi reformtervek között. Az egyeztetett, de a kormányrendeletben nem szereplő orvosképzési reformterv a kutatás számára nem volt elérhető.

\section{Professzori kinevezések a fordulat után}

Mivel a II. világháború után az orvostudományi karokon igen nagyszámú tanszék betöltetlen volt, ezért 19471948-ban a legtöbb professzori kinevezésre az OTK-n került sor. 1947 tavaszán egyetemi tanár lett a Pázmány Péter Tudományegyetemen Hedri Endre (1893-1962) és Sebestyén Gyula (1887-1954), a Szegedi Tudományegyetemen Huszák István (1906-1995), a Pécsi Tudományegyetemen pedig Környei István (1901-1988) és Szentágothai János (1912-1994). ${ }^{11} 1947$ nyarán újabb két professzori kinevezés is történt: Ökrös Sándor (19021987) és Kellner Béla (1904-1975) a Debreceni Tudományegyetemen lett egyetemi tanár. ${ }^{12} \mathrm{Az}$ ősz, illetve a tél folyamán lett professzor a Pécsi Tudományegyetemen Ernst Jenó (1895-1981), a szegedi egyetemen pedig Jáki Gyula (1898-1958). ${ }^{13}$

A Magyar Kommunista Párt Értelmiségi Osztály orvoscsoportjának 1948 februárjától májusáig terjedő munkatervében személyi kérdések is szerepeltek. Az MKP a Pázmány Péter Tudományegyetem Orvostudományi Karára - név feltüntetése nélkül - két orvosprofesszort kívánt kineveztetni. Hasonló elképzelése volt a pártnak a vidéki orvoskarokra is. 1948 elején lett egyetemi tanár a budapesti egyetemen Incze Gyula (1903$1955)$ és Sárkány Sándor (1906-1996), a tavasz folyamán újabb két kinevezésre került sor. Mindkét felterjesztett - Méhes Gyula (1897-1970) és Cholnoky László (1899-1967) - a Pécsi Tudományegyetemnek lett a professzora. ${ }^{14}$ A nyár folyamán lett egyetemi tanár ugyancsak a pécsi egyetemen Oravecz Pál (1895-1962) és Beöthy Konrád, a budapesti egyetemen Sós József (1906-1973) és Faragó Ferenc (1905-1950), a debrecenin pedig Kesztyús Loránd (1915-1979). ${ }^{15}$ Az 19471948-ban kinevezett orvosprofesszorok között több tudományos kiválóság volt. Egyesek már MTA-tagok voltak, néhányan közel álltak az akadémiai tagsághoz, többen pedig a későbbiek során lettek akadémikusok. Így Sebestyén Gyula (1887-1954), Környei István, Szentágothai János, Kellner Béla, Ernst Jenö, Cholnoky László, Sós József, valamint Kesztyüs Loránd.

\footnotetext{
1 Köznevelés, 1947. 7. szám.

2 Köznevelés, 1947. 14., 15. szám.

13 Köznevelés, 1947. 12. és 20. szám; Köznevelés, 1948. 1. és 2. szám.

14 PTI-Arch. 274-23/2.

${ }^{15}$ Köznevelés, 1948. 14. szám.
}

Nem lett akadémikus, de tüdőmútétei révén külföldön is híressé vált a későbbi Kossuth-díjas Sebestyén Gyula. Nemzetközi hírű volt a Stockholmi Orvosi Nobel Intézet egykori kutatója, az idegrendszer, az idegbetegségek, a szkizofrénia és a sclerosis multiplex területén elért eredményei révén Kossuth-díjat elnyert Huszák István. A további felterjesztettek „átlagos” szakmai-tudományos színvonalat képviseltek, de valamennyien megfeleltek az egyetemi tanári követelményeknek.

Ahhoz képest, hogy egyes politikai erők - különösen az MKP - fontosnak tartották a professzori kinevezéseket, az egyetemi tanári felterjesztéseknek nem volt különösebb sajtóvisszhangja.

Az 1946, 1947 és 1948-as tanévben lettek egyetemi rendkívüli tanárok: Cavallier József (1891-1970), Fejes Lajos, Bach Imre (1895-1996), Kassay Dezsö (18991981), Dobszay László (1914-1983), Issekutz Béla (1896-1979). ${ }^{16}$ Az egyetemi rendkívüli tanárok többsége szintén magas szakmai színvonalon állt, például Issekutz Béla már 1945 májusától az MTA rendes tagja volt.

\section{Magántanári habilitációk}

A tudományos utánpótlás szempontjából igen fontos habilitációk 1947-ben is folytatódtak. A különböző tudományterületeket elemezve megállapíthatjuk, hogy 19471948-ban hatvankilencen az orvostudományok terén szereztek magántanári fokozatot. 1947 márciusában habilitált Darabos László, Frankl József, Farádi László (1909-1993), Csermely Hubert. ${ }^{17}$ Májusban lett magántanár Ajkay Zoltán (1874-1951). ${ }^{18}$ Selley Camillo (1902-1979), Fischer Antal (1901-1979) és Pápolczy Ferenc (1901-1971) júniusban habilitált. ${ }^{19}$ Júliusban pedig öten szereztek fokozatot: Temesvári Miklos, Györffy István (1912-1999), Andi Tibor, Ötvös Ervin és Chatel Andor. ${ }^{20}$ Tizenöt magántanári fokozat született augusztusban: Ács Miklos, Hermann Vilmos, Horn Béla (19021983), Betsicht Andor, Noszkay Aurél (1900-1987), Murányi László, Nádrai Andor (1904-1965), Koppenstein Ernö (1901-1971), Schiffer Ernö (1893-1951), Thoroczkay Miklós, Borota (Böhm) Sándor, Pogány Ödön (1881-1967), Gottsegen György, Papp Károly, valamint Detre László (1897-1953). ${ }^{21}$

Szeptemberben szerzett fokozatot Zsebök Zoltán (1908-1953), Schulhof Ödön (1896-1978) és Stefancsik Szilárd,22 októberben pedig Csorna István és Cseh Imre. ${ }^{23}$ Novemberben, illetve decemberben lett habilitált doktor Jakabfi Imre, Habán György (1905-1976) és

\footnotetext{
${ }^{6}$ Köznevelés, 1946. 20. szám; Köznevelés, 1947. 12., 14. és 19. szám; Köznevelés, 1948. 9. és 15. szám.

7 Köznevelés, 1947. 4. és 5. szám.

8 Köznevelés, 1947. 10. szám.

9 Köznevelés, 1947. 12. szám.

Köznevelés, 1947. 14. szám.

Köznevelés, 1947. 15. és16. szám.

Köznevelés, 1948. 18. szám.

${ }^{23}$ Köznevelés, 1947. 19. és 20. szám.
} 
Róna Andor. ${ }^{24}$ 1948. januárban szerzi meg magántanári oklevelét Nemeskey Tivadar és Modrovich Emil. ${ }^{25}$ Február folyamán pedig négyen habilitáltak: Polgár István (1888-1954), Benkő Sándor (1912-1971), Gerlei Ferenc (1900-1970) és Kuncz Andor. ${ }^{26}$ Márciusban ketten védtek: Janicsin József és Beöthy Konrád (1898-1958). ${ }^{27}$ Május folyamán egy fó, Gaál István (1911-1963) szerzett fokozatot, júniusban pedig ketten: Makai Endre (1884-1970) és Fleischmann László (1872-1962). ${ }^{28}$ Júniusban Went Ferenc, júliusban pedig Szilárd Zoltán és Simkovics Gusztáv, augusztus folyamán Eisert Pongrád szerzett fokozatot. ${ }^{29}$ Augusztusban további három védésre került sor: Kulitzy Géza, Várady Szabó Miklós, valamint Matzy István személyében. ${ }^{30}$ A legtöbben 1948 októberében szereztek magántanári fokozatot: Gefferth Károly, Erdélyi Gyula, Ráth Zoltán, Horn Zoltán (19021970), Bálint Péter (1911-1998), Cserey Pechány Albin, Bartók Imre (1892-1979), Bíró László (1913-1971), Doby József, Dreguss Miklós, valamint Pesti Lajos. ${ }^{31}$

Az igen nagyszámú habilitált között sok kiváló szakember volt, többen a későbbiek során egyetemi tanárok lettek. Bálint Péter a vesefiziológia, valamint a vesepatológia nemzetközileg is jegyzett kutatójaként volt számon tartva, 1970-ben akadémiai tagságot is szerzett. Zsebők Zoltán a magyarországi orvostársadalom elismert professzorává vált, aki a radiológiai kutatások terén kimagaslót alkotott. Kiváló kutató lett Schulhof Ödön is, aki az ízületi megbetegedések szakértőjeként tette magánt ismertté. Jakabfi Imre pedig a debreceni egyetem profeszszoraként több generációt oktatott. Noszkay Aurél urológust a prosztata- és vesemútétek nemzetközileg kimagasló mûvelőjeként tartja számon a szakma. A habilitáltak többsége tudományosan felkészült orvosként segítette a színvonalas gyógyítást.

\section{Orvos rektorok és dékánok az egyetemeken}

A rektori kinevezések és a dékáni megbízatások nemcsak presztízst jelentenek a felsőoktatásban és a társadalomban, hanem bizalmi tisztségek is. Ezeknek az „állásoknak" különös fontossága 1946 őszétől lett, amikor a Magyar Kommunista Párt III. kongresszusán a párt szakított a pluralista demokráciával és meghirdette a népi demokratikus átalakulást. Ebben a rendszerben az autonómia helyett megnő az állami beavatkozás szerepe és a hatalomhoz való viszony is új helyzetet teremt az egyetemi vezetők számára. Érdeklődésre tarthat számot, hogy az

\footnotetext{
${ }^{24}$ Köznevelés, 1947. 22., 23. és 24. szám.

${ }^{25}$ Köznevelés, 1948. 3. szám.

${ }^{26}$ Köznevelés, 1948. 4. szám.

27 Köznevelés, 1948. 6. szám.

28 Köznevelés, 1948. 12. és 13. szám.

29 Köznevelés, 1948. 14. és 15. szám.

30 Köznevelés, 1948. 17. szám.

${ }^{31}$ Köznevelés, 1948. 19. szám.
}

orvostudományi elitből kik lettek a politikai fordulat után a rektorok és a dékánok.

A népi demokratikus átalakulás idején a magyarországi tudományegyetemeken két orvos rektor megválasztására került sor. Az 1947-1948-as tanévben nevezték ki Lissák Kálmánt (1908-1982) a Pécsi Tudományegyetem első számú vezetőjének, Debrecenben pedig Fornet Béla (1890-1988) lett a rektor. ${ }^{32}$ Lissák rektori megbízatását az 1948-1949-es tanévre meghosszabbították. ${ }^{33}$

Megállapíthatjuk, hogy mindkét rektor szakmai-tudományos szempontból nézve megérdemelten lett az intézmények vezetője. Lissák Kálmán nemcsak a fiziológia területén volt tudományos kiválóság, hanem baloldali gondolkodású értelmiségi volt, már 1945 októberében belépett a Magyar Kommunista Pártba. Az MTA 1948. július 2-i nagygyúlésén az Akadémia levelező tagjának választotta. Fornet Béla is magas színvonalon múvelte a belgyógyászatot. Kísérleti és klinikai kutatásokat végzett emésztőszervek kórélettanával kapcsolatosan, tanulmányait magyar és külföldi folyóiratok egyaránt megjelentették.

Lissák Kálmán rektori megbízatása előtt az 19461947-es tanévtől már betöltött magasabb vezetői funkciót a Pécsi Tudományegyetemen, ő volt az Orvostudományi Kar dékánja. 1946 ószétől lett dékán a debreceni egyetemen Verzár Gyula, Kanyó Béla (1898-1969) pedig a szegedi orvosi kart vezette. ${ }^{34}$ Az 1947-1948-as tanévtől a Pázmány Péter Tudományegyetem orvosi karának dékánja Melly József lett, a debreceni OTK élére Kovács Ferenc (1890-1974), a pécsi dékán Lajos László, a szegedi pedig Dávid Lajos lett (1889-1963). ${ }^{35}$

Az 1947-1948-as tanévtől Babics Antal (1902-1992) a budapesti OTK dékánja, Töró Imre (1900-1993) a debreceni, Ivanovics György (1904-1980) pedig a pécsi orvoskari dékán. ${ }^{36}$

A politikai fordulat ellenére a magasabb vezetői tisztséget betöltő orvosok szakmai-tudományos szempontból megfeleltek a kinevezési elvárásoknak. Verzár Gyula, a fül-orr-gégészet professzora a sebgyógyulással kapcsolatosan végzett jelentős kutatásokat. Számos tudományos közleménye jelent meg hazai és nemzetközi folyóiratokban. Kanyó Béla pedig a közegészségtan kiváló mưvelője volt és a növényvédő szerekre vonatkozó kutatások elismert tekintélye. Melly József iskolaorvosként fejtett ki jelentős elméleti és gyakorlati munkásságot. Kovács Ferenc nőgyógyászati, hormonológiai kutatásai révén nemzetközileg is jegyzett professzor volt. Lajos László is iskolateremtő egyéniség volt. Főleg szülészeti és nőgyógyászati endokrinológiával foglalkozott.

Dávid Lajos a gyógyszerészképzés és gyógyszerkutatás nemzetközileg is jegyzett szakértője volt. Babics Antal

\footnotetext{
Köznevelés, 1947. 16. szám

3 Köznevelés, 1948. 16. szám.

34 Köznevelés, 1946. 19. szám.

5 Köznevelés, 1947. 16. szám.

${ }^{6}$ Köznevelés, 1948. 16. szám.
} 
kiváló urológus, 1949-től az MTA tagja, Törő Imre anatómus pedig már 1946-tól volt az MTA tagja. Szintén 1946-tól tagja a testületnek a víruskutató Ivanovics György.

Megállapítjuk, hogy politikai és világnézeti felfogásuktól függetlenül valamennyien kiváló kutatók és oktatók voltak az orvoskari dékánok.

\section{Orvosok}

\section{a Magyar Tudományos Akadémián}

A népi demokratikus átalakulás időszakában három olyan nagygyúlés volt az MTA-n, ahol új tagokat választott a testület. Az orvosok közül 1946. december 19-én rendes tag lett Ernst Jenó, Jancsó Miklós, Mansfeld Géza, Rusznyák István, Sántha Kálmán, Törö Imre és Haynal Imre (1892-1979). ${ }^{37}$ A megválasztott akadémikusok szakmai-tudományos szempontból valamennyien megfeleltek az akadémikusokkal szemben támasztott követelményeknek. Mivel 1946-ban a júliusi nagygyưlés után ez volt a második tagválasztó ülés és már „egyértelművé” vált a népi demokratikus átalakulás, ezért többnyire a baloldali gondolkodású jelöltek kerültek be a testületbe.

A következő tagválasztás 1947. június 6-án történt. Mindösszesen egy orvos lett az MTA tagja. Ekkor lett az Akadémia tagja Környey István, aki az agyi keringés és érelmeszesedés terén elért kutatásokkal vált érdemessé az akadémiai tagságra. ${ }^{38}$

Már a kiépült diktatúra idején, 1948. július 2-án történt a következő tagválasztás. Ekkor választották az

37 A Magyar Tudományos Akadémia Tagjai 1825-1973. Összeállította: Fekete Gézáné. Budapest, 1975, 550. oldal.

38 A Magyar Tudományos Akadémia Tagjai 1825-1973, 550. oldal.
MTA tagjai közé Haranghy Lászlót (1897-1975), Keller Bélát, Kerpel-Fronius Ödönt (1906-1985), Krompecher Istvánt (1905-1983), Lissák Kálmánt, Szentágothai Jánost, Went Istvánt (1899-1963) és Baló Józsefet (1895-1979). ${ }^{39}$

A taggyúlésre és tagválasztásra különösebb érdeklődés és véleménynyilvánítás nélkül került sor. A tudományos közélet hangulatát befolyásolta, hogy a rossz kutatási lehetőségek és a kiépülő diktatúra miatt az orvostudományi elitnek a tudománypolitikát meghatározó tagjai közül Szent-Györgyi Albert és Laki Kálmán már Nyugatra távoztak. 1947 nyarától nemcsak a régi rendszerhez kötődő orvostudományi elit érezte magát mind tudományosan, mind egzisztenciálisan veszélyeztetve, hanem az új elit néhány tagja is, olyanok, akik 1945 után - sőt egyesek az 1948-as tagválasztás idején - lettek akadémikusok. Az MTA 1949. november 29-i „átszervezése” idején Went Istvánt és Baló Józsefet gyakorlatilag megfosztották testületi tagságuktól. Az 1949-es átszervezés alkalmából 161 főt „minősítettek” át, illetve fosztottak meg akadémiai tagságuktól, ebből heten voltak orvosok. Szent-Györgyi Albertet és Laki Kálmánt külföldre távozásuk miatt távolították el, viszont Baló József és Went István esetében nem lehettek különösebb szakmai-politikai indokok, mégis távozniuk kellett. Rehabilitációjukra az MTA 1989. évi közgyúlése alapján került sor.

(N. Szabó József dr., Nyíregyháza, Sóstói u. 31/B, 4400 e-mail: n.szabo.jozsef@nye.hu)

39 A Magyar Tudományos Akadémia Tagjai 1825-1975, 550. oldal.

\section{Pályázati felhívás}

Professzor Dr. Fehér János munkássága, szakmai és erkölcsi hagyatéka páratlan és maradandó az orvostudományban. Ezért a Semmelweis Egyetem Általános Orvostudományi Kar II. sz. Belgyógyászati Klinika volt igazgatója, „A hepatológiai szabad gyökös és immunológiai vonatkozásai” című program vezetőjének, az Orvosi Hetilap főszerkesztőjének emlékére Alapítvány létesült. Az alapítványt a Fővárosi Bíróság 2011. március 7-én 11.335. sorszám alatt nyilvántartásba vette.

Dr. Fehér János Emlékére Alapítvány fő célja: a belgyógyászat, különösen a hepatológia szabad gyökös és immunológiai vonatkozásai témakörök kutatásának fejlesztése, támogatása, illetve ösztönzése oly módon, hogy a fiatal egyetemi oktatók és hallgatók az alapítvány kamatából részesüljenek. Az alapitvány célja olyan orvosok, PhD-hallgatók díjazása, akik kiemelkedő tudományos munkát végeznek és eredményeiket az Orvosi Hetilapban publikálják.

A dolgozatot „Dr. Fehér János pályázat” megjelölésével kell benyújtani.

A pályázatot 2017. április 5-ig lehet beküldeni a Kuratórium elnökének (Dr. Rácz Károly) vagy titkárának (Dr. Lengyel Gabriella) - Semmelweis Egyetem, II. sz. Belgyógyászati Klinika, 1088 Budapest, Szentkirályi u. 46. címre.

A pályázathoz mellékelni kell a pályázó önéletrajzát és a dolgozatot.

A dijjak odaítéléséről a kuratórium dönt. A dij átadására a Markusovszky ünnepségen kerül sor. Az ünnepségen a nyertes pályázó maximum 5-10 perces előadásban foglalja össze az eredményeit. 